\title{
Peertechz
}

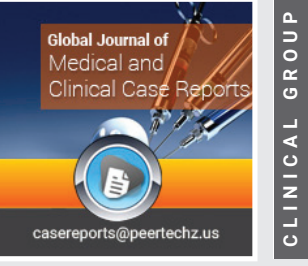

\section{The glycocalyx may play an important role in Preventing Sepsis Campaign in China (PSCC)}

\author{
Yan Chai', Yi-Peng Fang', Zhen-Yu Zhang ${ }^{1,2}$, Zhe Guo ${ }^{1,2}$, \\ Hui-Juan Zhang ${ }^{1,2}$, Xue-Song Wang ${ }^{1}$, Hai-Yan Liao', Zi-Wen \\ Wang ${ }^{1}$ and Zhong Wang ${ }^{1,2 *}$
}

${ }^{1}$ School of Clinical Medicine, Tsinghua University, Beijing 100084, China

${ }^{2}$ Beijing Tsinghua Changgung Hospital, Tsinghua University, Beijing 102218, China

Received: 04 April, 2021

Accepted: 21 April, 2021

Published: 22 April, 2021

*Corresponding author: Zhong Wang, Beijing Tsinghua Changgung Hospital, Tsinghua University, Beijing 102218, China, E-mail: wangzhong523@vip.163.com, wz523@mail.tsinghua.edu.cn

https://www.peertechzpublications.com

Check for updates

\section{Abstract \\ Sepsis is a common clinical emergency and critical illness, whose prevention and treatment are mainly to protect organ functions. Glycocalyx is a polysaccharide- protein composite structure on the surface of endothelial cells, which has the functions of protecting cell barriers and maintaining organ perfusion. It may protect the organ function, and prevent the infected patients from progressing to sepsis by monitoring of glycocalyx in the serum. This article mainly summarized the cause of PSCC and the possible role of glycocalyx in PSCC to provide reference for clinical intervening.}

Sepsis is a life-threatening organ dysfunction caused by the body's excessive response to infection [1]. It is one of the most common critical illnesses in emergency department(ED) and intensive care unit (ICU), which has a high fatality rate and occupies a large consumption of medical resources. According to statistics, more than 350,000 patients die of sepsis in Europe and the United States each year, and the treatment cost are as high as 25 billion dollars [2]. There are more than 18 million severe sepsis cases worldwide each year, and the number of patients is increasing at a rate of $1.5 \%$ per year [3].

An epidemiological survey in China shows that the hospitalization expenses for patients with severe sepsis reached (92259 \pm 92786$)$ yuan in 2010 , and the average daily expenditure was $(4066 \pm 3248)$ yuan [4]. The number of deaths due to sepsis in China is about 1 million every year [5]. Based on this grim situation, The American Society of Critical Care Medicine and the European Critical Care Association launched the "Sureviving Sepsis Campaign" (SSC) to call for everyone to pay attention to sepsis in 2002 . However, the fatality rate of sepsis remains high yet after 20 years of SSC, although doctors have a better understanding for the pathophysiology of sepsis. The effect of SSC is unsatisfactory.

Among the many methods of diagnosis and treatment in SSC, the Early Goal-Directed Therapy (EGDT) proposed by EMANUEL RIVERS in Henry Ford Hospital was once considered the most feasible way to treat septic shock [6], which is widely praised. But the ProCESS, PRISE, and ProMISe[4,7,8]. in the subsequent three clinical trials for sepsis showed that EGDT did not reduce 90-day case fatality rate in patients with septic shock. On the contrary, the consequences were higher organ failure scores, longer cardiovascular support time, and more ICU hospitalization due to the high-intensity treatments that EDGT advocated, such as the infusion of more intravenous fluids, vasoactive drugs and albumin, etc. In the end, someone put forward that EDGT was completely unsuitable for clinical application. But, we think that most of reaserches aimed at ICU patients and inpatients, so the results may have selection bias. Therefore, it is not that EDGT is wrong, but that the "early" patients are completely unavailable in the ICU [9]. 
The background of sepsis is infection by definition. There is a SIRS process from infection to sepsis. Only cutting off the path that infection progresses to SIRS is the real early stage. In this sense, EDGT should be implemented in the ED, not in the ICU.

Infectious diseases are the most common diseases in the $\mathrm{ED}$, the department that infected patients visit often firstly is ED. The progression from infection to sepsis contains a series of pathophysiological processes. If intervention in this process is applied, the incidence of sepsis must be reduced. The latest definition of sepsis is "organ dysfunction caused by the body's overreaction to infection" [1]. Therefore, there is no sepsis without infection, and the body's response to pathogenic microorganisms. The infection cannot progress to sepsis.

As we all know, the local manifestations of infection include "redness, swelling, heat, and pain." "Red" is due to local tissue congestion; "swelling" is due to local fluid exudation; "hot" is due to abundant blood flow; "pain" is due to increased release of bradykinin and serotonin. Therefore, we can infer that "redness, heat and pain" is the body's normal reaction at the infected site, and it is the process that immune substances penetrating through the capillary to the infected area to kill the infectious pathogen. But if this reaction is generalized to the whole body, it will cause the body's systemic overreaction, which will lead to SIRS.

SIRS is the body's overreaction to infection, which can lead to systemic microcirculation dysfunction.This is considered to be a key link in the pathophysiological process of sepsis $[10,11]$ Both clinical and experimental studies have confirmed that endothelial cell damage is closely related to organ damage in sepsis, and the prognosis of patients can be effectively improved by improving endothelial cell function. This therapeutic effect is mostly achieved by improving the microcirculation function [11]. The integrity of the endothelial cell barrier is destroyed which leads to excessive leakage of fluid and protein in sepsis. And a large amount of plasma protein penetrating into the interstitial space results in hypovolemia, hypoproteinemia, tissue edema, and capillary leakage. In further development, patients may have tissue hypoperfusion, manifesting as hypoxemia, oliguria or anuria, systemic edema, and even multiple organ dysfunction syndrome (MODS) [12], which affect the patient's prognosis. One of the early mechanisms of this capillary permeability change is the destruction of the glycocalyx on the surface of the vascular endothelium.

Glycocalyx is a layer of fluffy polysaccharide-protein composite structure covering the side surface of the vascular endothelial cavity. It is mainly composed of proteoglycan, CD44(glycoprotein) and glycosaminoglycan. The core transmembrane protein of glycosaminoglycan and glycosaminoglycan chain are connected with endothelial cells to form an endothelial barrier. The glycocalyx restricts the transport of liquid and plasma macromolecules to endothelial cells through negative electricity and network structure, maintaining fluid balance and endothelial cell homeostasis, and regulating the interaction between blood cells and endothelial cells [13]. Inflammatory factors causing by severe infection destroy the integrity of the glycocalyx and the barrier function of endothelial cells in SIRS, which leads to fluid leakage. Research by Eric P Schmidt et al showed that glycocalyx damage can be detected in the blood within 30 minutes in infected mice [14]. Many documents have confirmed that the detection of serum glycocalyx components, especially the glycocalyx skeleton component sydecan-1, are assessing the progress of sepsis [15] and judging the prognosis of patients with sepsis. It can be inferred that if the time of glycocalyx destruction is discovered in time for patients with high risk of sepsis, glycocalyx may be an early diagnosis of sepsis. And the protection of glycocalyx structure may prevent sepsis and reduce the incidence of sepsis $[16,17]$.

In summary, we need to adopt diagnostic and treatment measures for emergency patients with infections to block the pathway from infection to sepsis. In other words, we need to establish a new EGDT to prevent sepsis in the ED. However, how to define our "early (E)" and how to determine our "goal (G)" are still challenges we are facing. However, it is possible to identify patients who may develop sepsis in infected patients earlier, and provide accurate prevention of capillary leakage at an earlier stage, including starting from monitoring the changes in glycocalyx components in the blood, and protecting glycocalyx on the endothelial cells. improve hemodynamic changes, especially microcirculation changes, prevent infected patients from progressing to sepsis, and block the process of sepsis.

\section{References}

1. Singer M, Deutschman CS, Seymour CW, Shankar-Hari M, Annane D, et al (2016) The third international consensus definitions for sepsis and septic shock (sepsis-3). JAMA 315: 775-787. Link: https://bit.ly/3n56Q7D

2. Gaieski DF, Edwards JM, Kallan MJ, Carr BG (2013) Benchmarking the incidence and mortality of severe sepsis in the united states. Crit Care Med 41: 1167-1174. Link: https://bit.ly/2QJu7Qa

3. Martin GS, Mannino DM, Eaton S, Moss M (2003) The epidemiology of sepsis in the united states from 1979 through 2000. N Engl J Med 348: 1546-1554. Link: https://bit.ly/3ni3myR

4. Mouncey PR, Osborn TM, Power GS, Harrison DA, Sadique MZ, et al. (2015) Trial of early, goal-directed resuscitation for septic shock. N Engl J Med 372 1301-1311. Link: https://bit.ly/3gvW3Sy

5. Weng L, Zeng XY, Yin P, Wang LJ, Wang CY, et al. (2018) Sepsis-related mortality in china: a descriptive analysis. Intensive Care Med 44: 1071-1080. Link: https://bit.ly/32vTVSN

6. Rivers E, Nguyen B, Havstad S, Ressler J, Muzzin A, et al. (2001) Early goaldirected therapy in the treatment of severe sepsis and septic shock. $\mathrm{N}$ Engl $\mathrm{J}$ Med 345: 1368-1377. Link: https://bit.ly/20nWjbw

7. Investigators $P$, Yealy DM, Kellum JA, Huang DT, Barnato AE, et al. (2014) A randomized trial of protocol-based care for early septic shock. N Engl J Med 370: 1683-1693. Link: https://bit.ly/3aoGM24

8. Peake SL, Delaney A, Bailey M, Bellomo R, Cameron PA, et al. (2014) Goaldirected resuscitation for patients with early septic shock. N Engl J Med 371 1496-1506. Link: https://bit.ly/3n8Afhm

9. Mentzoni I, Bogstrand ST, Faiz KW (2019) Emergency department crowding and length of stay before and after an increased catchment area. BMC Health Serv Res 19: 506. Link: https://bit.ly/2RNCyKV 
10. Hariri G, Joffre J, Leblanc G, Bonsey M, Lavillegrand JR, et al. (2019) Narrative review: clinical assessment of peripheral tissue perfusion in septic shock. Ann Intensive Care 9: 37. Link: https://bit.ly/2RH5gwX

11. Colbert JF, Schmidt EP (2016) Endothelial and microcirculatory function and dysfunction in sepsis. Clin Chest Med 37: 263-275. Link: https://bit.ly/3sGOTOe

12. Siddall E, Khatri M, Radhakrishnan J (2017) Capillary leak syndrome: etiologies, pathophysiology, and management. Kidney Int 92: 37-46. Link: https://bit.ly/3xcu1Bo

13. Uchimido R, Schmidt EP, Shapiro NI (2019) The glycocalyx: a novel diagnostic and therapeutic target in sepsis. Critical Care 23: 16. Link: https://bit.ly/3xcupzQ
14. Yang Y, Schmidt EP (2013) The endothelial glycocalyx: an important regulator of the pulmonary vascular barrier. Tissue Barrier 1: e23494 Link: https://bit.ly/32wg7fx

15. Ikeda $M$, Matsumoto $H$, Ogura $H$, Hirose T, Shimizu $K$, et al. (2017) Circulating syndecan-1 predicts the development of disseminated intravascular coagulation in patients with sepsis. J Crit Care 43: 48-53. Link: https://bit.ly/3n4ZjFX

16. Burke-Gaffney A, Evans TW (2012) Lest we forget the endothelial glycocalyx in sepsis. Crit Care 16: 121. Link: https://bit.ly/3tF5HWD

17. Smart L, Macdonald SPJ, Burrows S, Bosio E, Arendts G, et al. (2017) Endothelia glycocalyx biomarkers increase in patients with infection during emergency department treatment. J Crit Care 304-309. Link: https://bit.ly/3tJdJ12

\section{Discover a bigger Impact and Visibility of your article publication with}

\section{Peertechz Publications}

\section{Highlights}

* Signatory publisher of ORCID

* Signatory Publisher of DORA (San Francisco Declaration on Research Assessment)

* Articles archived in worlds' renowned service providers such as Portico, CNKI, AGRIS, TDNet, Base (Bielefeld University Library), CrossRef, Scilit, J-Gate etc.

* Journals indexed in ICMJE, SHERPA/ROMEO, Google Scholar etc.

* OAI-PMH (Open Archives Initiative Protocol for Metadata Harvesting)

* Dedicated Editorial Board for every journa

* Accurate and rapid peer-review process

* Increased citations of published articles through promotions

* Reduced timeline for article publication

Submit your articles and experience a new surge in publication services (https://www.peertechz.com/submission).

Peertechz journals wishes everlasting success in your every endeavours.

Copyright: ( 2021 Chai Y, et al. This is an open-access article distributed under the terms of the Creative Commons Attribution License, which permits unrestricted use, distribution, and reproduction in any medium, provided the original author and source are credited.

Citation: Chai Y, Fang YP, Zhang ZY, Guo Z, Zhang HJ, et al. (2021) The glycocalyx may play an important role in Preventing Sepsis Campaign in China (PSCC). Glob J Medical Clin Case Rep 8(1): 031-033. DOI: https://dx.doi.org/10.17352/2455-5282.000122 